\title{
Goiás na arquitetura geopolítica da América portuguesa
}

\author{
Fernando Lobo Lemes[1]
}

\begin{abstract}
Resumo
A estratégia adotada pelo rei de Portugal a partir dos anos 1740, com a fragmentação da jurisdição eclesiástica do Rio de Janeiro e a instalação das Capitanias de Goiás e Mato Grosso, imprime uma nova orientação na diplomacia de Lisboa com relação à América portuguesa. Nesse contexto, buscamos compreender o novo estatuto das minas de Goiás nas negociações que visam garantir e ampliar o controle da administração colonial sobre os territórios situados na fronteira com o império espanhol.

Palavras-chave: Goiás; geopolítica; fronteira.
\end{abstract}

\section{Goiás en la arquitectura geopolítica de la América portuguesa}

\section{Resumen}

La estrategia adoptada por el rey de Portugal desde los años 1740, con la fragmentación de la jurisdicción eclesiástica de Río de Janeiro y la instalación de las Capitanías de Goiás y Mato Grosso, imprime una nueva orientación en la diplomacia de Lisboa referente a la América portuguesa. Por lo tanto, se buscó comprehender el nuevo estatuto de las minas de Goiás en las negociaciones, con el objetivo de asegurar y ampliar el control de la administración colonial sobre los territorios situados en la frontera con lo imperio español.

Palabras-clave: Goiás; geopolítica; frontera.

\section{Goiás in the geopolitical architecture of the Portuguese America}

\begin{abstract}
The strategy adopted by the king of Portugal from the decade of $1740 \mathrm{on}$, with the fragmentation of the ecclesiastical jurisdiction of Rio de Janeiro and the implementation of the captaincies of Goiás and Mato Grosso, gives a new orientation to Lisbon diplomacy in relation to Portuguese America. In this context, we seek to understand the new statute of the mines of Goiás in the negotiations aiming to guarantee and to enhance the colonial administration control over the territories situated by the frontier with the Spanish empire.
\end{abstract}

Keywords: Goiás; geopolitics; frontier.

\section{Goiás dans l'architecture géopolitique de l'Amérique portugaise}

\section{Resumé}

La stratégie adoptée par le roi du Portugal dans les années 1740, avecla fragmentation de la juridiction ecclésiastique du Rio de Janeiro et l’installationdes Capitaineries du Goiás et Mato Grosso, imprime une nouvelle orientation dans la diplomatie de Lisbonne. Dans ce contexte, nous cherchons à comprendre le nouveau statut des mines du Goiás dans les négociations qui envisagent garantir les territoires dans la frontière avec l'empire espagnol.

Mots-clés: Goiás; géopolitique; frontière. 
$\mathrm{P}$ or meio do estímulo à fundação de vilas e cidades e da implementação de aparatos administrativos, jurídicos e religiosos, o rei de Portugal buscou consolidar sua presença estratégica na fronteira oeste da América portuguesa. Nesse aspecto, a segunda metade do século XVIII assistiu à ocupação da região como forma de estabelecimento das bases materiais do domínio português frente ao domínio espanhol. ${ }^{1}$

Com esse objetivo, as estratégias adotadas pela diplomacia portuguesa imprimiam, em dois sentidos, um novo rumo ao projeto de Lisboa para as minas de Goiás. Em primeiro lugar, foi criada a prelazia de Goiás, confirmada pela Bula do papa Bento XIV, em 1746, vinculada ao Bispado de Mariana, fruto da fragmentação da jurisdição eclesiástica do Rio de Janeiro. Em segundo lugar, o desmembramento da Capitania de São Paulo permitiu a criação das Capitanias de Goiás e de Mato Grosso. Conjugadas, essas ações emprestariam a Vila Boa - criada em julho de 1739 e única vila existente na região das minas de Goiás durante todo o século XVIII — uma nova dimensão em meio às negociações que visavam garantir e ampliar os limites da fronteira oeste da América portuguesa. Nesse cenário, as duas iniciativas promoveram o redimensionamento das minas de Goiás no contexto regional, reposicionando, a partir da nova geopolítica Imperial, as ações e o papel desempenhados por Vila Boa de Goiás enquanto espaço político e econômico essencial na região da fronteira.

\section{A criação da prelazia de Vila Boa de Goiás}

A criação da prelazia de Vila Boa de Goiás obedeceu a um calendário intimamente associado às negociações estabelecidas entre Lisboa e Roma. Em consulta ao governador da Capitania de São Paulo, em 1719, membros do Conselho Ultramarino em Lisboa já revelavam preocupações com relação à necessidade de se criarem de novos bispados que tivessem atuação no interior da América portuguesa. A par das necessidades espirituais e religiosas dos fiéis que habitavam uma vasta região sob a responsabilidade única do bispado do Rio de Janeiro, a iniciativa visava, sobretudo, ampliar a presença da Coroa e da Igreja nos novos territórios conquistados, desestimulando, em contrapartida, a movimentação dos espanhóis e coibindo, ao mesmo tempo, os altos índices de contrabando do ouro produzido nos territórios dedicados à mineração. ${ }^{2}$

Considerando a vastidão do território que se encontrava sob a jurisdição da diocese do Rio de Janeiro - que compreendia toda a Capitania de São Paulo, inclusive as regiões de Minas Gerais, Goiás e Mato Grosso, além de todo o restante sul da América portuguesa -, as correspondências trocadas entre os membros do Conselho Ultramarino e o soberano português

'A respeito das definições das fronteiras na América portuguesa, ver Maria Fernanda Batista Bicalho, "Sertão de Estrelas. A Delimitação das Latitudes e das Fronteiras na América Portuguesa”, Varia Historia, vol. 21, Belo Horizonte, 1999, p. 73-85.

${ }^{2}$ Cristina de Cássia Pereira Moraes, "Deus e o Diabo no sertão dos Guayazes: abusos e desmandos do vigário da Vara de Vila Boa", Sociedade e Cultura, vol. 9, n. 1, Goiânia, 2006, p. 91. 
revelam a consciência da Coroa a respeito das dificuldades existentes em função da vastidão territorial daquele bispado. Essa situação certamente estimulou o interesse do monarca em promover seu desmembramento, ${ }^{3} \mathrm{O}$ que foi efetivamente proposto a partir de 1745, por meio da intervenção pessoal do rei D. João $\mathrm{V}$ junto à Sé Apostólica, solicitando a criação dos bispados de São Paulo e Ribeirão do Carmo, bem como das prelazias de Goiás e Cuiabá. ${ }^{4}$

Por esse caminho, o monarca português propunha a Roma um novo mapa para a jurisdição eclesiástica na América, reordenando a geografia do bispado do Rio de Janeiro, que passaria a limitar-se ao sul pelo rio Paraíba, marco inicial do futuro bispado de São Paulo, cuja jurisdição, por sua vez, se prolongaria até o extremo sul da América portuguesa. A oeste, a jurisdição do Rio de Janeiro manteria seu alcance até a fronteira com o novo bispado da Vila de Ribeirão do Carmo, compreendendo o território da Capitania de Minas Gerais (com exceção das regiões do São Francisco e Paracatu, que se encontravam sob a jurisdição, respectivamente, dos bispados de Pernambuco e da Bahia), limitado ao norte pelo arcebispado da Bahia e a oeste pela prelazia de Goiás. ${ }^{5}$

Apesar de a intervenção da Coroa junto ao papado tratar especificamente do desmembramento da diocese do Rio de Janeiro, a resposta da Cúria Romana não contemplou imediatamente os interesses de Lisboa, argumentando a impossibilidade da emissão de uma bula papal que atendesse, ao mesmo tempo, à criação de bispados na América e na Ásia:

Tratando-se de um indulto geral para todos os Bispados eretos, e a erigir-se tanto na America, quanto na Ásia, não é possível que se inserisse numa Bula duas ereções pares. [...] não se faz possível um indulto tão amplo e tão ilimitado. ${ }^{6}$

Contudo, outro fator interpunha um novo gênero de dificuldade para uma decisão de Roma favorável ao Império português: a mobilização da Coroa espanhola. Incomodados com a diplomacia agressiva levada a cabo pelo monarca luso e pela indefinição dos limites geográficos entre os dois impérios na América do Sul - que envolvia, notadamente, a região das

\footnotetext{
${ }^{3} \mathrm{AHU} / \mathrm{GO} / \mathrm{AnexO}$ ao ofício do ouvidor-geral de Goiás, Francisco de Atouguia Betencourt e Lira, ao secretário de estado da Marinha e Ultramar, Francisco Xavier de Mendonça Furtado, remetendo os autos de informação sobre os fatos denunciados contra o ex-governador e capitão-general de Goiás, conde de São Miguel, D. Álvaro José Xavier Botelho Távora, e o ex-ouvidor-geral de Goiás, Antônio da Cunha Sotomaior; Vila Boa de Goiás, 29 de maio de 1760 [Cx. 17, D. 988]. Biblioteca da Ajuda, Códice 1173, cota 49 - VTTT-41. Ver também Cristina de Cássia Pereira Moraes, op cit., p. 93.

${ }^{4} \mathrm{AHU} / \mathrm{GO} / \mathrm{Consulta}$ do Conselho Ultramarino, ao rei D. João V, sobre a criação dos bispados de São Paulo e Ribeirão do Carmo, no distrito do Bispado do Rio de Janeiro, como também as prelazias de Goiás e Cuiabá no mesmo distrito; acerca das côngruas que devem ter os bispos prebendados e capelães; os meios que se apontam para as despesas; os edifícios das catedrais e os lugares em que devem ser fundadas; Lisboa, 10 de abril de 1745 [Cx. 3, D. 264].

${ }^{5}$ Cristina de Cássia Pereira Moraes, "Deus e o Diabo no sertão dos Guayazes: abusos e desmandos do vigário da Vara de Vila Boa", Sociedade e Cultura, vol. 9, n. 1, Goiânia, 2006, p. 94.

${ }^{6}$ Biblioteca da Ajuda, Códice 1173, cota 49 - VTTT-4, citado em Cristina de Cássia Pereira Moraes, "Deus e o Diabo no sertão dos Guayazes: abusos e desmandos do vigário da Vara de Vila Boa", Sociedade e Cultura, vol. 9, n. 1, Goiânia, 2006, p. 93.
} 
minas de Goiás e a de Cuiabá - , os espanhóis discordavam da concessão de uma nova jurisdição eclesiástica que beneficiasse as pretensões de Portugal, temendo, exatamente, a ameaça de sua hegemonia na fronteira, assegurada pelo Tratado de Tordesilhas. ${ }^{7}$

Sabendo que a autorização pela Sé Apostólica para a criação de bispados com base no direito canônico estava associada à definição dos limites de suas prováveis jurisdições, o rei de Portugal agia com o intuito de garantir o domínio sobre um território que interessava, ao mesmo tempo, à Coroa de Espanha. Para isso, contava com os privilégios provenientes do padroado e do regalismo que, sob a égide da religião, faziam do rei de Portugal uma espécie de vigário apostólico que representava os interesses da Igreja tanto no reino quanto nos territórios de conquista, cabendo a Roma ratificar as escolhas feitas pelo monarca na esfera espiritual. ${ }^{8}$

Como o monarca português havia determinado a criação dos novos bispados e prelazias na América, o papa Bento XIV promulgou, em 1746, a Bula Candor Lucis Eternae, erigindo as dioceses de São Paulo e Mariana, bem como as prelazias de Goiás e Cuiabá. ${ }^{9}$ Escorando-se nas possibilidades abertas pelo padroado régio e em uma estratégia deliberada que visava consolidar a ocupação dos territórios localizados além do meridiano definido pelo Tratado de Tordesilhas, o rei de Portugal obtinha, assim, as bênçãos e o reconhecimento

\footnotetext{
乙Única referência a respeito da divisão territorial entre Portugal e Espanha na América, o Tratado de Tordesilhas, assinado em 7 de junho de 1494, dividiu o mundo em dois hemisférios, através de um meridiano distante 370 léguas das ilhas de Cabo Verde, deixando à Espanha tudo que ficasse no Ocidente e a Portugal o que se contivesse no Oriente. O acordo estabelecia o prazo de dez meses para que fosse demarcada a linha divisória entre as possessões dos dois reinos. Contudo, a linha nunca chegaria a ser efetivamente fixada. Sua localização nos mapas era um exercício de projeção conceitual que não levava em conta nem os aspectos físicos e geográficos, nem a ocupação do território. Sobre o assunto, ver Íris Kantor, "Diplomatic uses of Brazil's island myth cartographic and historiographic polemics", Varia historia, vol. 23, n. 37, 2007, p. 70-80. Ver também Luis Adão da Fonseca, O tratado de Tordesilhas e a diplomacia luso-castelhana no século XVI, Lisboa, Edições Enapa, 1991.

${ }^{8} \mathrm{O}$ direito de padroado do rei, instituído no século XVI por D. João III, abrangia os bispados das terras conquistadas por Portugal e criados pelo monarca, tanto no reino como no ultramar. Era a Santa Sé que indigitava as pessoas e provia os bispados, apesar de aceitar propostas da Coroa para não causar conflitos. Reis como D. Afonso III, D. Manuel, Filipe I, D. João IV e D. Pedro II tentaram constantemente conseguir o direito de padroado e imiscuir-se no da Santa Sé. Em 1740, o papa Bento XIV decidiu dar ao rei de Portugal o direito dos benefícios dos novos bispados, reservando-se, no entanto, à nomeação dos bispos, cônegos e outras dignidades dos bispados antigos. Esse regime de padroado real, na prática, manteve-se até a Lei de Separação, de 1911, já depois da instauração da República em 1910. Baseado nessa concepção, o rei de Portugal conquistou o privilégio de indicar o núncio apostólico em Portugal, além de propor nomes para os bispados vagos em todo o reino, sendo-lhe conferido, por Bento XIV, em dezembro de 1748, o título de Rei Fidelíssimo. Cf. Cristina de Cássia Pereira Moraes, "Deus e o Diabo no sertão dos Guayazes: abusos e desmandos do vigário da Vara de Vila Boa", Sociedade e Cultura, vol. 9, n. 1, Goiânia, 2006, p. 94. Sobre o Padroado no Império português, ver Charles R. Boxer, Portuguese society in the tropics. The municipal councils of Goa, Macao, Bahia and Luanda. 1510-1800, Madison and Milwaukee, The University of Wisconsin Press, 1967 e Idem, A Igreja e a Expansão Ibérica, 14401770, Lisboa, Edições 70, 1990. Sobre o Padroado português no Oriente, ver Antônio da Silva Rego, O Padroado Português do Oriente e a sua historiografia, 1838-1950, Lisboa, Academia Portuguesa de História, 1978. Idem, Le Patronage portugais de I'Orient, Lisboa, Agência Geral do Ultramar, 1957 e Teotônio R. de Souza, "O Padroado português do Oriente visto da Índia. Instrumentalização política da religião", Revista Lusófona de Ciência das Religiões, n. 13/14, 2008, p. 413-430.

'Luiz Antônio da Silva e Souza, "Memória sobre o descobrimento, governo, população e cousas mais notáveis da Capitania de Goyaz (1812)", In: José Mendonça Teles, Vida e obra de Silva e Souza, Goiânia, UFG, 1998, p. 107.
} 
de Roma à sua expansão em direção ao oeste e às violações dos acordos estabelecidos naquele Tratado. ${ }^{10}$

Criados os bispados de São Paulo e Mariana em 1745, as prelazias de Goiás e Mato Grosso apenas foram efetivamente instaladas em 1749. Coincidentemente, no mesmo ano do desmembramento da Capitania de São Paulo, em função da criação das Capitanias de Goiás e Cuiabá.

\section{A criação das Capitanias de Goiás e Mato Grosso}

A ideia de criar uma Capitania autônoma em Goiás, separada daquela de São Paulo, foi aventada durante a década de 1730, como alternativa para a implantação inicial dos mecanismos de controle pensados em Lisboa. Assim, antes mesmo da provisão real que determinava a instalação da primeira vila nas minas de Goiás, o governador Antônio Luís de Távora, Conde de Sarzedas, ainda em 1735, preocupado com a situação de conflito permanente que caracterizava a região e consciente da necessidade de apresentar uma alternativa à debilidade da presença dos poderes reguladores da Coroa, convoca uma junta extraordinária na cidade de São Paulo em que estavam em pauta dois projetos: a criação de uma Capitania ou a instalação de uma vila em Sant'Anna ou Meia Ponte. Com a chegada do Comissário Real, Martinho de Mendonça ${ }^{11}$ ao Brasil, enviado pelo rei de Portugal com o objetivo de analisar a questão, prevalece o segundo projeto, em detrimento do primeiro. ${ }^{12}$

Num segundo momento, em 1736, na mesma oportunidade em que o monarca determina ao então governador de São Paulo, Antônio Luiz de Távora, o Conde de Sarzedas, a criação de uma vila nas minas de Goiás, insistia também num parecer sobre a necessidade da instalação de um governo separado da Capitania de São Paulo:

Faço saber a vós Conde de Sarzedas Governador e Capitão General da Capitania de São Paulo que como tenho resoluto passeis as minas dos Goyas e nelas determineis sitio para se fundar uma Vila Sou servido ordenar-vos por Resolução de sete deste presente mês e ano em consulta do meu conselho Ultramarino informeis exatamente de tudo o que naqueles distritos necessitar de providencia, e se deve formar-se nos ditos Goyas Governo Separado, ou mais Vilas e justiças para que eu resolva o que me parecer conveniente. ${ }^{13}$

\footnotetext{
${ }^{10}$ Conforme afirma Jaime Cortesão, "Portugal obtinha do Papa o reconhecimento e uma sansão transcendente à sua expansão para oeste e, por conseguinte, às suas violações do Tratado de Tordesilhas". Esse ato "se revertia a favor de Portugal e não da Espanha e implicava uma antecipação sob a espécie de uti possidetis religioso". Cf. Jaime Cortesão, Alexandre de Gusmão e o Tratado de Madri, Rio de Janeiro, Instituto Rio Branco, 1952, p. 175. "Sobre a trajetória do Comissário Real Martinho de Mendonça de Pina e de Proença, enviado pelo rei de Portugal, em meados da década de 1730, para auxiliar os governadores da porção sul da América portuguesa, ver Irenilda Reinalda B. R. M Cavalcante, O comissário real Martinho de Mendonça: práticas administrativas na primeira metade do século XVIII, Tese de Doutorado em História, UFF, Rio de Janeiro, 2010.

12José Martins Pereira de Alencastre, Anais da Provincia de Goiás (1863), Goiânia, Governo de Goiás, 1979, p. 56. ${ }^{13} \mathrm{AHU} / \mathrm{GO} / \mathrm{Carta}$ do governador e capitão-general de São Paulo, Luís de Mascarenhas, ao rei D. João V. em resposta à provisão de 11 de fevereiro de 1736, sobre a grande distância entre São Paulo e as Minas de Goiás e a necessidade de esta última ter o seu próprio governo; Vila Boa de Goiás, 30 de setembro de 1739 [CX. 1, D. 68].
} 
Porém, a resposta ao rei não seria enviada por Sarzedas, morto em Goiás em agosto de 1737, mas por seu sucessor, Luiz de Mascarenhas. ${ }^{14}$ Aproveitando sua presença nas minas, logo após ter realizado o ritual de instalação de Vila Boa e do Senado da Câmara, escreve ao rei emitindo sua opinião sobre o assunto. Aparentando tanto uma justificativa para sua permanência em Goiás quanto uma argumentação convincente para que se constituísse uma Capitania autônoma, o governador, após apontar a longa distância entre as minas e a cidade de São Paulo, as dificuldades para a abertura do caminho terrestre, em substituição às rotas fluviais então existentes, para as minas de Cuiabá e a atenção que se deveria dispensar à Fazenda Real e, em especial, ao recolhimento do quinto, defende a presença de um governador nas minas:

[...] porque com as suas ordens se executa melhor, e mais prontamente qualquer diligência do Real Serviço [...]. E pelos referidos fundamentos me parece deve assistir o Governador nestas minas e não em São Paulo porque na dita cidade nem é, nem pode ser útil a sua assistência. ${ }^{15}$

Numa outra oportunidade, em março de 1737, o superintendente-geral das minas de Goiás, Gregório Dias da Silva, também sugeria ao monarca a criação de uma nova Capitania, apostando na possibilidade de uma ampla jurisdição, que incluísse e submetesse até mesmo as minas de Cuiabá. ${ }^{16}$

\section{As Capitanias de Goiás e Mato Grosso constituem entrelaçamentos de uma arquitetura política e administrativa que anunciam as intenções de Lisboa para essa intrincada região de fronteira}

\footnotetext{
${ }^{14}$ Antônio Luís de Távora foi governador da Capitania de São Paulo de 15 de agosto de 1732 até sua morte, no arraial de Traíras, nas minas de Goiás, em 29 de agosto de 1737.

${ }^{15} \mathrm{AHU} / \mathrm{GO}$, Carta do governador e capitão-general de São Paulo, Luís de Mascarenhas, ao rei D. João V, em resposta à provisão de 11 de fevereiro de 1736, sobre a grande distância entre São Paulo e as Minas de Goiás e a necessidade de esta última ter o seu próprio governo; Vila Boa de Goiás, 30 de setembro de 1739 [Cx. 1, D. 68]. ${ }^{16} \mathrm{AHU} / \mathrm{GO} / \mathrm{Carta}$ do superintendente-geral das Minas de Goiás, Gregório Dias da Silva, ao rei D. João V, sobre a devassa tirada contra os moradores das Minas do Tocantins, os quais pediam melhoramento no valor da capitação, devido à diminuição dos seus jornais e respondendo à provisão que the ordenava informasse acerca de tudo o que necessitava, e se devia formar governo separado ou mais vilas e justiças. Vila Boa de Goiás, 19 de março de 1737 [Cx. 1, D. 31].
} 
ao invés da criação imediata de uma Capitania autônoma, em razão da importância estratégica que representavam as vilas no seio do espaço colonial. ${ }^{17}$ Assim sendo, apenas em 1748, o rei de Portugal anuncia a criação da Capitania de Goiás e, ao mesmo tempo, a de Mato Grosso, mandando informar ao governador Luiz de Mascarenhas sobre o desmembramento da Capitania de São Paulo:

Tendo S. M. tomado em consideração a necessidade que havia de repartir a Capitania geral [...] por não permitir a sua vasta extensão que possam ir em tempo as providencias necessárias nos remotíssimos que compreende, residindo o governador a grande distancia deles, foi servido criar dois governos e Capitanias gerais, a primeira no Mato Grosso que entra em toda a comarca do Cuiabá até o rio Grande, e a segunda em Goiás $[. . .]^{18}$

Desta forma, os procedimentos para a instalação da nova Capitania, bem como o provimento dos respectivos cargos, são desencadeados rapidamente. Em 26 de julho de 1748, o monarca nomeia Marcos de Noronha, então governador da Capitania de Pernambuco, para o cargo de governador ${ }^{19}$ e publica

\footnotetext{
${ }^{17} \mathrm{~A}$ respeito do papel estratégico e a função desempenhadas pelas vilas e cidades no mundo colonial e, mais especificamente, na América portuguesa, existe uma vasta bibliografia disponível. Dentre outras: Renata Malcher de Araújo, "A Razão na selva: Pombal e a reforma urbana da Amazônia”, Camões. Revista de Letras e Culturas Lusófonas, n. 15-16, 2003, p. 151-165; Idem., A urbanização do Mato Grosso no século XVIII. Discurso e método. Tese de Doutorado em História da Arte, Universidade Nova de Lisboa, Lisboa, 2000; Maria Fernanda Batista Bicalho, A cidade e o Império: o Rio de Janeiro no século XVIII, Rio de Janeiro, Civilização Brasileira, 2003; Idem, "O Rio de Janeiro no século XVIII: A transferência da capital e a construção do território centro-sul da América portuguesa", Centro Interdisciplinar de Estudo da Cidade/Unicamp (on-line). Disponível em: <http://www.ifch.unicamp.br/ciec/revista/artigos/dossie1.pdf>. Acesso em: 15 de junho de 2009; Nasr Fayad Chaul; Luís Sérgio Duarte (orgs.), As cidades dos sonhos: Desenvolvimento urbano em Goiás, Goiânia, UFG, 2004; Laurent Vidal (org.), La Ville au Brésil (XVIIle$X X e$ ). Naissances, renaissances, Paris, Les Indes Savants, 2008; Cláudia Damasceno Fonseca, Des terres aux villles de l'or. Pouvoir et territoires urbains au Minas Gerais (Brésil, XVIIIe siècle), Paris, Centre Culturel Calouste Gulbenkian, 2003; Rita Costa Gomes, "A Reconquista e o imaginário da cidade peninsular", In: Yvette Kace Centero; Lima de Freitas, Simbólica do espaço: Cidades, Ilhas, Jardins, Lisboa, Estampa, 1991, p. 43-57; Nauk Maria de Jesus, "A Câmara da Vila Real do Senhor Bom Jesus do Cuiabá: um breve panorama (1727-1800)", Fronteiras, vol. 10, n. 17, Dourados, 2008, p. 163-175; Idem, Na trama dos conflitos. A administração na fronteira oeste da América portuguesa (1719-1778), Tese de Doutorado em História, UFF, Rio de Janeiro, 2006; Mary Karasch, "The periphery of the periphery? Vila Boa de Goiás, 1780-1835", In: Christine Daniels; Michael V. Kennedy, Negotiated Empires. Centers and Peripheries in the Americas, 1500-1820, New York, Routledge, 2002, p. 143-169; Magnus Roberto Pereira de Mello, A forma e o podre: duas agendas da cidade de origem portuguesa nas idades medieval e moderna, Tese de Doutorado em História, UFPR, Curitiba, 1998; Fernando Lobo Lemes, "Pouvoir colonial et réseau urbain: Vila Boa de Goiás au XVIIIe siècle", In: Martine Acera; Guy Martinière; Guy Saupin; Laurent Vidal (orgs.), Les Villes et le monde. Du Moyen Âge au XXe siècle, Rennes, Presses Universitaires de Rennes, 2011, p. 107-127; Catarina Madeira Santos, Goa é a Chave de Toda a India. Perfil Político da Capital do Estado da Índia (1505-1570), Lisboa, CNCDP, 1999; Laurent Vidal, "Os trilhos da história do Brasil urbano", Ler História, n. 48, 2005, p. 75-85; Idem, "Capitais sonhadas, capitais abandonadas. Considerações sobre a mobilidade das capitais nas Américas (séculos XVIII - XX)", História, vol. 30, n. 1, 2011, p. 3-36; Idem, Mazagão: la ville que traversa I'Atlantique - Du Maroc à I'Amazonie (1769-1783), Paris, Flammarion, 2005; e, Idem, "Sous le masque du colonial - Naissances et "décadence" d’une Vila dans le Brésil moderne: Vila Boa de Goiás au XVIIIe siècle," Annales HSS, n. 3, 2007, p. 577-606.

${ }^{18} \mathrm{AHG}$ [Arquivo Histórico de Goiás]/DA [Documentos Avulsos], Carta do Secretário de Estado a Luiz de Mascarenhas, governador de São Paulo, comunicando a divisão da Capitania; Goiás, 17 de maio de 1748. ${ }^{19} / d e m$, Decreto do rei D. João V nomeando o [conde dos Arcos], Marcos de Noronha, governador e capitãogeneral de Goiás; Lisboa, 26 de julho de 1748 [Cx. 5, D. 374].
} 
edital em Lisboa para a seleção dos interessados no cargo de secretário de governo da Capitania de Goiás. ${ }^{20}$

Em janeiro de 1749, o monarca determina a transferência imediata de Marcos de Noronha, para que assuma o governo de Goiás. ${ }^{21}$ Ao chegar em Vila Boa, encontra-se com o povo do lugar e com os oficiais do Senado da Câmara que o aguardavam para investi-lo efetivamente dos poderes conferidos pelo cargo de governador da nova Capitania de Goiás. A celebração desse encontro foi descrita pelo também recém-nomeado secretário de governo, Ângelo Santos Cardoso, na ata oficial da solenidade:

Aos 8 dias do mês de Novembro de 1749, nesta Vila Boa de Goiás, nas casas da câmara dela, na presença do Senado da Câmara da mesma vila e povo dela, sendo aí lida a patente real com que Sua Majestade faz e nomeia governador e capitão-general destas minas ao Ilustríssimo e Excelentíssimo Sr. D. Marcos de Noronha, em virtude de que tomou posse do mesmo governo. De que fiz este termo, em que assinaram o dito Ilustríssimo e Excelentíssimo Sr. governador e capitão-general e oficiais da câmara. — E eu Ângelo dos Santos Cardoso, secretário do governo, o escrevi e assinei. D. Marcos de Noronha. Ângelo dos Santos Cardoso. Agostinho Luiz Ribeiro. Manoel da Silva. Inácio Barbosa da Silva. João Ferreira Barros. ${ }^{22}$

Criadas simultaneamente, as Capitanias de Goiás e Mato Grosso, além das similaridades que guardam entre si, constituem entrelaçamentos de uma arquitetura política e administrativa que anunciam a materialização de um mesmo projeto: as intenções de Lisboa para essa intrincada região de fronteira da América.

Situada na região central do continente sul-americano, tendo a mineração como principal atividade econômica e localizada em área de fronteira com os domínios

\footnotetext{
${ }^{20} \mathrm{AHG}$ [Arquivo Histórico de Goiás]/DA [Documentos Avulsos], Requerimento de Clemente Carlos de Azevedo Cotrim, ao rei D. João V, solicitando ser provido no cargo de secretário do governo da Capitania de Goiás; Lisboa, 5 de agosto de 1748 [Cx. 5, D. 376]; Idem, Consulta do Conselho Ultramarino, ao rei D. João V, sobre a nomeação de pessoas para o cargo de secretário do governo de Goiás; Lisboa, 8 de agosto de 1748 [Cx. 5 , D. 378]. Na verdade, parece tratar-se de um leilão do cargo de secretário de governo das minas de Goiás, que seria ocupado por aquele que pagasse maior valor pelo ofício. De acordo com António Manuel Hespanha, uma provisão real de 1740 alargou o regime do donativo a todos os ofícios do ultramar. Desde então, o preenchimento dos ofícios passou a ser feito por meio de leilão, onde eram vendidos àqueles que mais ofereciam. Essa transação não correspondia a uma verdadeira venda, já que o montante pago consistia em mera doação ligada ao dever de gratidão para com o monarca que concedia o oficio. Mesmo que o sistema de leilão tenha elevado a renda fiscal, a venda desses postos oficiais acabava prestigiando grupos rivais que, em função de acirradas disputas, ofereciam doações de montantes mais significativos, com eventuais prejuízos do interesse público e das pessoas de mais mérito, mas de menor fortuna. Cf. António Manuel Hespanha, "A constituição do Império português. Revisão de alguns enviesamentos correntes", In: João Fragoso; Maria Fernanda Bicalho; Maria de Fátima Gouvêa (orgs.), O Antigo Regime nos Trópicos: a dinâmica imperial portuguesa (séculos XVI-XVIII), Rio de Janeiro, Civilização Brasileira, 2001, p. 184-185.

${ }^{21}$ Governador da Capitania de Pernambuco e, mais tarde, vice-rei do Brasil, a indicação de Marcos de Noronha para o cargo de governador de Goiás segue uma tendência comum desde o século XVII, no Império português. Boa parte dos territórios brasileiros era governada por membros da "primeira nobreza". De acordo com Nuno Gonçalo Monteiro, é o caso, por exemplo, da Bahia, mesmo depois da transferência da capital para o Rio de Janeiro; de Goiás, a partir de 1749; Grão-Pará, Mato Grosso, Minas Gerais, Pernambuco, Rio de Janeiro (até 1763) e São Paulo (depois de 1721). Quanto mais se adentra o século XVIII, o Brasil torna-se tendencialmente o único destino colonial possível para os sucessores das casas de principal nobreza do reino. Cf. Nuno Gonçalo Monteiro, "Trajetórias sociais e governo das conquistas: notas preliminares sobre os vice-reis e governadores-gerais do Brasil e da Índia nos séculos XVII e XVIII", In: João Fragoso; Maria Fernanda Bicalho; Maria de Fátima Gouvêa (orgs.), op cit., p. 281. 22José Martins Pereira de Alencastre, Anais da Provincia de Goiás (1863), Goiânia, Governo de Goiás, 1979, p. 88.
} 
hispânicos - exatamente em face das províncias de Moxos e Chiquitos -, a fundação da Capitania de Mato Grosso revela a intenção da Coroa portuguesa em efetivar suas conquistas territoriais na região, detendo, sobretudo, o avanço das missões jesuíticas espanholas que buscavam se estabelecer na margem direita do rio Guaporé. ${ }^{23}$

A criação das duas Capitanias num único ato denuncia a relevância da decisão do monarca português (Mapa 1). Apontando a importância das regiões mineiras de Goiás e Mato Grosso no contexto do Império português, a interessante análise de Nauk Maria de Jesus indica sua posição como espaço estratégico de coesão das conquistas portuguesas na América.

Mais que isso, vê a região enquanto ponto de conexão entre o norte e o sul, através das bacias platina e amazônica, lugar de passagem do meridiano divisor dos domínios portugueses e hispânicos e espaço de clivagem entre dois impérios (Portugal e Espanha) e dois Estados (do Brasil e do Grão-Pará). ${ }^{24}$

De fato, não há dúvidas quanto ao significado das ações impulsionadas por Portugal nessa zona delicada de fronteira. De Lisboa, o olhar do rei de Portugal estava assentado preferencialmente sobre a região de Mato Grosso: se a criação de Vila Boa de Goiás foi pensada e efetivada apenas durante a década de 1730, Vila Real do Senhor Bom Jesus do Cuiabá antecedeu em uma década as pretensões da Coroa na região, notadamente por sua posição privilegiada a oeste, avançada em território teoricamente hispânico.

Não é por acaso que, ainda em julho de 1726, Rodrigo César de Menezes, então governador de São Paulo, seguindo o longo roteiro fluvial Tietê-Cuiabá, parte do porto de Araritaguaba em direção ao arraial de Senhor Bom Jesus do Cuiabá - cuja origem confunde-se, tal qual o arraial de Sant'Anna, com a descoberta das primeiras jazidas de ouro, em 1722. Seu objetivo era fundar a primeira vila nas minas de Cuiabá. Em janeiro de 1727, repetindo o mesmo ritual de criação de vilas adotado no Império português, demarca os lugares dos edifícios públicos, levanta o pelourinho com a participação dos moradores do lugar e elege os juízes ordinários e vereadores, instalando, logo em seguida, o Senado da Câmara de Vila Real do Senhor Bom Jesus de Cuiabá.

Ao contrário de Goiás, que durante todo o século XVIII teve Vila Boa como única vila, a Capitania de Mato Grosso logo receberia uma nova capital. Em 1752, é criada a Vila Bela da Santíssima Trindade, fundada para ser sede de governo, onde estavam o governador, as tropas militares, a provedoria, a intendência, a ouvidoria e a casa de fundição do ouro. Em cada uma das vilas, funcionava um Senado da Câmara. Posteriormente, foram criados os fortes de Coimbra e Príncipe da Beira, bem como as vilas de Albuquerque, Vila Maria e Casalvasco. A estratégia política levada a cabo é evidente, pois, por meio da criação de vilas e da instalação de fortificações, a iniciativa portuguesa estabeleceria total domínio sobre essa região, fechando-a aos espanhóis.

\footnotetext{
${ }^{23}$ Nauk Maria de Jesus, "A câmara da Vila Real do Senhor Bom Jesus do Cuiabá: um breve panorama (17271800)", Fronteiras, vol. 10, n. 17, Dourados, 2008, p. 164.

${ }^{24} \mathrm{~A}$ importância das Capitanias de Goiás e Mato Grosso tem sido, ao longo de muito tempo, minimizada pela historiografia, como lembra oportunamente Nauk Maria de Jesus. Segundo ela, na "história do Brasil colonial a área mineira por excelência é Minas Gerais e a fronteira considerada mais conflitante é o sul, sendo minimizada nesse contexto a fronteira oeste e também a norte". Cf. Nauk Maria de Jesus, op cit.
} 


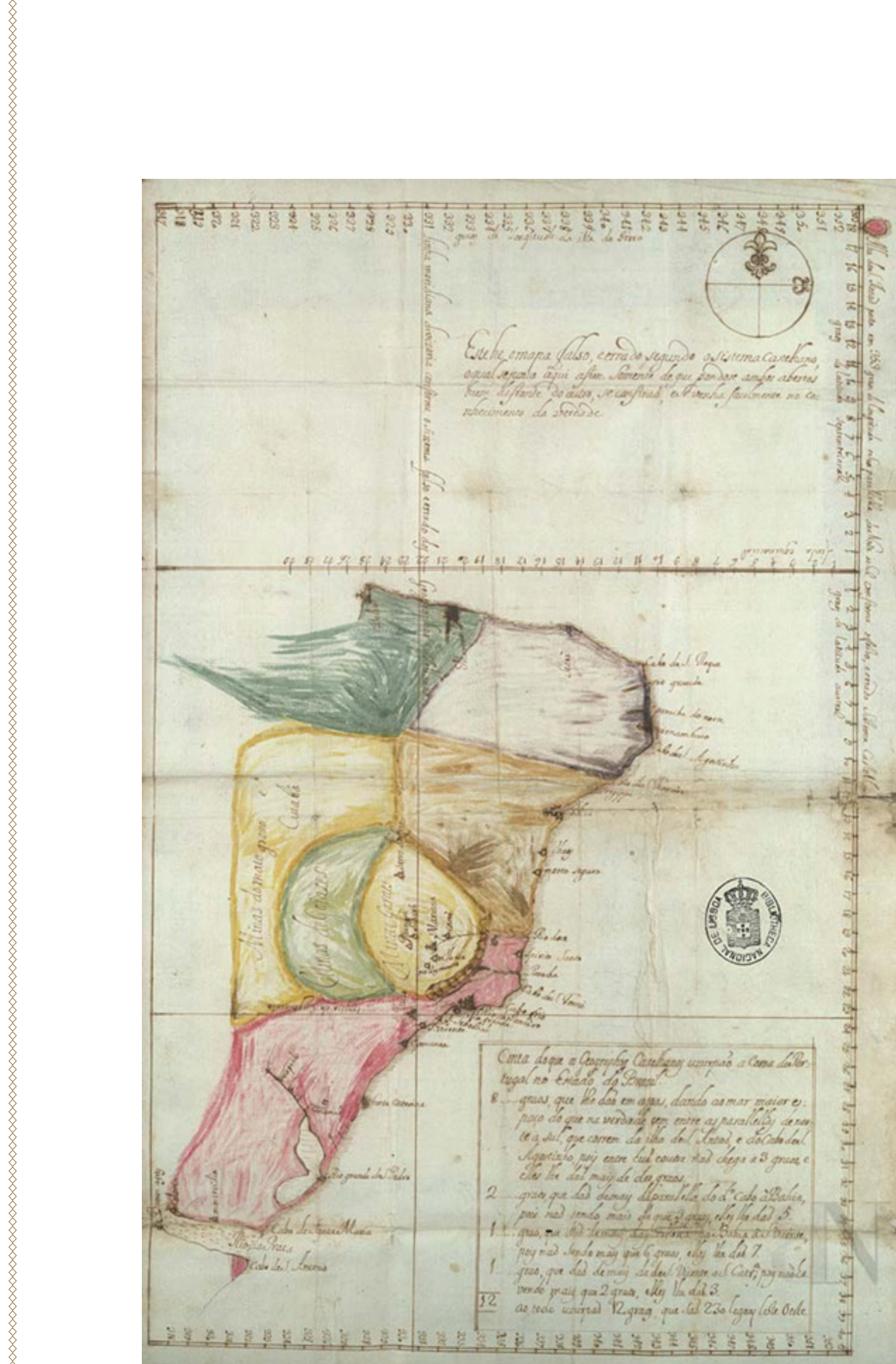

Mapa 1. Situação política da América portuquesa: ao centro e à esquerda, as Capitanias de Goiás e Mato Grosso. ${ }^{2}$

aFrancisco de Seixas, fl. ca. 1767. In: Noticias dos Titulos do Estado do Brazil e de seos limites austraes e septemtrionaes no temporal/Francisco de Seixas. - [1767]. - Entre f. [13] e 1. Pertence à Livraria de Alcobaça. Mapa político/Brasil, ca. 1767. CDU: 918.1(084.3). 912"17”(084.3). COD. 1408. A cartografia do Brasil nas Coleções da Biblioteca Nacional (1700-1822), Biblioteca Nacional, Lisboa. 
Neste contexto, os enormes esforços e grandes investimentos realizados nessa fronteira entre os dois impérios eram estimulados por um olhar entrecortado que indicava a necessidade de garantir a Portugal a posse sobre a maior extensão territorial possível, preservando os espaços ocupados e suas riquezas naturais. Por um viés geograficamente invertido, o olhar do rei de Portugal justificava seus avanços no front de combate frente aos interesses hispânicos: estava exatamente na manutenção dessa fronteira a garantia dos limites que consolidavam e ofereciam um novo formato à América portuguesa. Visualizando no sentido inverso ao movimento histórico da ocupação da América, as conquistas da Coroa se estendiam desde a última fronteira definida pela Capitania de Mato Grosso até os confins do litoral cercado pelas praias do oceano Atlântico. É este o sentido das palavras do governador da Capitania de Mato Grosso, Luiz de Albuquerque de Mello Pereira e Cáceres, quando escrevia aos governadores de Goiás, descrevendo a importância do lugar que governava. A função de Mato Grosso consistia, sobretudo, na defesa dos “[...] ultimos Dominios de Sua Magestade, que cobrem por este Lado, todos os outros da America".25

\section{O caminho de Goiás: oxigênio para a região de Mato Grosso}

Do nosso ponto de vista, é a grandiosidade que essa fronteira representa para a monarquia que vai regular os índices de importância das minas e, mais tarde, da Capitania de Goiás, no interior do projeto colonial conduzido por Lisboa. Num primeiro momento, as minas de Goiás oxigenam a região do Mato Grosso, imprimindo novo alento às minas de Cuiabá, ao servir de caminho terrestre alternativo à rota fluvial, única ligação existente com a cidade de São Paulo. O trajeto das monções, como eram conhecidas as navegações fluviais em direção ao oeste da América, era realizado através de rios que faziam a ligação de São Paulo a Cuiabá, com inúmeros perigos e dificuldades, numa viagem com duração média de cinco a seis meses. Esse percurso foi substituído pelo caminho terrestre aberto entre Vila Boa de Goiás e a Vila Real do Senhor Bom Jesus do Cuiabá. ${ }^{26}$

A soma de diversos fatores estimulou a abertura desse caminho alternativo. Certamente, a expansão e aumento da produção do ouro, a pressão das correntes migratórias em direção a Goiás e Mato Grosso e os interesses comerciais

\footnotetext{
${ }^{25} \mathrm{AHU} / \mathrm{GO} / \mathrm{Anexo}$ do ofício do governador e capitão-general de Goiás, barão de Mossâmedes, José de Almeida Vasconcelos de Soveral e Carvalho, ao secretário de estado da Marinha e Ultramar, Martinho de Melo e Castro, remetendo certidão de todas as remessas de ouro enviadas em socorro à capitania de Mato Grosso. Vila Boa de Goiás, 22 de junho de 1774 [Cx. 27, D. 1779].

${ }^{26}$ As monções foram expedições fluviais próprias do século XVIII, partindo do porto paulista de Araritaguaba, atual Porto Feliz, no Vale do Médio Tietê, e demandando as minas de ouro de Cuiabá, no Mato Grosso. Percorriam cerca de 3.500 quilômetros por diversos rios, entre corredeiras, saltos e ataques indígenas, para o fornecimento de víveres, produtos manufaturados e transporte de homens e de ouro. Pelo conjunto de peculiaridades, técnicas específicas de marinharia e fabricação de canoas, bem como pela coleção de ocorrências trágicas, as monções se revestiram, ao longo dos tempos, de uma aura de empreitada grandiosa, quase absurda, semilendária. Seu desaparecimento deveu-se à abertura de caminhos terrestres por Goiás e ao advento das tropas de mulas. Cf. Valderez Antônio da Silva, Os fantasmas do rio: um estudo sobre a memória das monções do Vale do Médio Tiete, Dissertação de Mestrado em História Cultural, Unicamp, Campinas, 2004.
} 
em jogo alimentaram a necessidade de uma via de ligação entre essas duas regiões pertencentes a um mesmo conjunto econômico e social, o "complexo da mineração".27

Além disso, mesmo antes do desmembramento da Capitania de São Paulo e a criação das Capitanias de Goiás e Mato Grosso, a insegurança com relação aopanorama geopolítico local, que permeava as representações a respeito da presença dos espanhóis do outro lado da fronteira, denunciava os limites do caminho fluvial e, ao mesmo tempo, encorajava as ações de integração territorial na região, traduzidas pela abertura do caminho terrestre até as minas de Goiás. Estimulados por frequentes notícias e rumores de conflitos entre os dois impérios, autoridades locais viam na ligação terrestre com o arraial de Sant'Anna e, mais tarde, Vila Boa, uma via de contato eficaz em caso de necessidade de abastecimento, fuga ou apoio militar, como demonstra a preocupação dos oficiais do Senado da Câmara de Cuiabá, em abril de 1736:

[...] nas últimas canoas que vieram do povoado havia chegado a notícia de se fazerem grandes preparos, não somente no reino, mas em toda esta América para a guerra que por instantes se esperavam declaradas com a Coroa de Castela e por esta terra poder ser invadida pelos castelhanos em breve tempo, sem ter aonde lhe venha socorro, mais do que pela viagem do rio e este pode estar impedido pelos inimigos e por estas razões e por outras mais $[\ldots]^{28}$

Pouco tempo depois, a mesma ansiedade é manifestada pelos oficiais da Câmara, agora associada a outra razão: somada aos riscos da viagem e à possibilidade de guerra contra os castelhanos, a insegurança das monções está diretamente relacionada com a arrecadação da Fazenda Real.

[...] se entende havendo forma e caminho seguro para a arrecadação da Real Fazenda, como declara a ordem de Sua Majestade e pela viagem do rio não é seguro o caminho, porque além dos grandes riscos que há de cachoeira e gentio que tem investido as nossas tropas como proximamente sucedeu na do presente, os perigos dos Castelhanos por causa das guerras podem com facilidade destruir as nossas tropas e para melhor segurança das remessas do ouro da Real Fazenda, bem comum do povo e conservação desta terra para o qual tem Sua Majestade recomendado que faça toda a humana diligência, em se abrir o dito caminho [para Goiás]. ${ }^{29}$

Coincidentemente, o mesmo problema estava presente nas preocupações do governador de São Paulo, Luiz de Assis Mascarenhas, reveladas em carta ao rei D. João V, três anos mais tarde. Mais contundente, escrevendo de Vila Boa,

\footnotetext{
${ }^{27}$ Alcir Lenharo, Crise e mudança na frente oeste de colonização, Ensaios 1, Cuiabá, UFMT/PROEDI, 1982, p. 17-19.

${ }^{28}$ Auto e Termo da Junta do Senado da Câmara da Vila Real do Senhor Bom Jesus do Cuiabá, de 18 de abril de 1736, UFMT/NDHIR, Microficha n. 14, D. 176

${ }^{29}$ Auto e Termo da Junta do Senado da Câmara da Vila Real do Senhor Bom Jesus do Cuiabá, de 18 de abril de 1736, UFMT/NDHIR, Microficha n. 14, D. 176.
} 
sua opinião quanto às consequências perniciosas da navegação para o desenvolvimento da região de Mato Grosso deixa entrever sua preferência e o valor que atribui ao caminho terrestre entre Cuiabá e Goiás. Segundo ele,

Uma grande parte desta Capitania são as Minas do Cuyabá as quais pela dificuldade da navegação para elas se não acham ainda tão povoadas como já estariam se se houvesse estabelecido caminho por terra e como desta Vila [Vila Boa] há de presente uma picada aberta pela qual já tem ido gente com mais segurança de suas vidas e fazendas do que pelo caminho da navegação e em menos tempo convém muito que esta se freqüente para maior utilidade dos povos, e mais segurança dos quintos reais os quais já para o ano seguinte poderão vir por ela $[\ldots]^{30}$

Assim, no final de 1739, Assis Mascarenhas anunciava ao monarca que, a partir de 1740, o quinto real, recolhido nas minas de Cuiabá, poderia seguir em direção à Casa de Fundição de São Paulo pelo caminho terrestre que passaria por Vila Boa de Goiás, garantindo-se mais rapidez e segurança. No interior do conjunto da mineração, as microfronteiras vão sendo, pouco a pouco, integradas, dando forma à América portuguesa: o caminho da Bahia às Minas Gerais e Goiás é complementado e estendido até as minas de Cuiabá.

\section{Na fronteira entre dois impérios: o ouro de Goiás transferido para Mato Grosso}

Nessa geografia do ouro, se a comunicação por terra com as minas de Goiás representa importante avanço para a manutenção da fronteira oeste da América, a criação de Vila Boa e, posteriormente, a instalação das Capitanias de Mato Grosso e Goiás, intensificam ainda mais essa conexão, transferindo, como veremos, para as minas de Goiás, grande parte da responsabilidade pelo financiamento das ações levadas a cabo por Lisboa, visando garantir a posse e o controle da região.

Com a nomeação de Marcos de Noronha como primeiro governador de Goiás, a comunicação com as minas de Cuiabá e a transferência de importantes somas em ouro para a Capitania de Mato Grosso estão entre as primeiras instruções do monarca, enviadas em janeiro de 1749. Em resposta ao rei de Portugal, quanto ao caminho novo para Cuiabá, o governador afirmou estar

[...] muito adiantada esta comunicação [...] por que os viandantes, e sertanejos tem conhecido que com vinte e cinco dias de viagem podem transportar as suas carregações deste àquele governo, $\mathrm{e}$ a grande utilidade que disto lhe resulta, espero que seja o meio

\footnotetext{
${ }^{30} \mathrm{AHU} / \mathrm{GO} / \mathrm{Carta}$ do governador e capitão-general de São Paulo, Luís de Mascarenhas, ao rei D. João V, em resposta à provisão de 11 de fevereiro de 1736, sobre a grande distância entre São Paulo e as Minas de Goiás e a necessidade de esta última ter o seu próprio governo; Vila Boa de Goiás, 30 de setembro de 1739 [CX. 1, D. 68].
} 
mais eficaz para que se deixem persuadir das muitas instâncias, que farei todas as possíveis para que se continuem este caminho. ${ }^{31}$

Quanto à ajuda de custo que, de acordo com as instruções de Lisboa, devia encaminhar ao governador de Mato Grosso, Marcos de Noronha se dispôs a ajudar, mas alegou que, inicialmente, não seria possível enviar os recursos financeiros solicitados pelo monarca. Entretanto, não tardou muito para que a Coroa determinasse o estabelecimento de uma contribuição anual em ouro, proveniente das minas de Goiás, com a finalidade de sustentar as tropas militares e remunerar funcionários com a função de demarcar os limites geográficos com a América espanhola. ${ }^{32}$

Na verdade, se a intenção de Lisboa era promover a integração espacial do conjunto minerador na América, caberia à Capitania de Goiás, a partir de 1751, o papel de provedora das ações desencadeadas em Mato Grosso. Desde então, o ouro de Goiás passou a garantir o apoio logístico e material indispensáveis para a promoção da integridade da fronteira, por meio da manutenção de atividades militares, demarcação dos limites geográficos do território ocupado pelos portugueses e construção de fortificações, iniciativas que visavam à consecução dos projetos do monarca português contra as pretensões da Coroa hispânica.

\section{As peculiaridades da região de fronteira, a insegurança e o receio dos espanhóis operavam a favor da Capitania de Mato Grosso}

Com essa finalidade, a partir de 1757, o rei de Portugal reafirma a obrigação de uma remessa anual para a Capitania de Mato Grosso, embora não tenha fixado a quantia exata dos valores que deveriam ser transferidos. E para não deixar dúvidas quanto à importância que dá aos investimentos e transferências de recursos que financiam os movimentos na fronteira, autoriza o envio, caso necessário, do ouro pago pela provedoria da Fazenda Real ou pela tesouraria dos Quintos, recolhido na Capitania de Goiás. Assim, não havendo ouro disponível nos cofres da provedoria,

[...] o ouro necessário para as ditas remessas as mandareis sempre fazer efetivas, até pelos produtos dos Meus Reais Quintos; por que a tudo anteponho a providencia de não faltarem os meios para a subsistência das Tropas, e para a administração da justiça, em

\footnotetext{
${ }^{31} \mathrm{AHU} / \mathrm{GO} / \mathrm{Carta}$ do governador e capitão-general de Goiás, conde dos Arcos, Marcos de Noronha, ao rei D. João V em resposta à provisão sobre o melhoramento da comunicação entre Goiás e Cuiabá e acerca da ajuda de custo concedida a Mato Grosso; Vila Boa de Goiás, 18 de dezembro de 1749 [Cx. 5, D. 420].

${ }^{32}$ Cristina de Cássia Pereira Moraes, "Deus e o Diabo no sertão dos Guayazes: abusos e desmandos do vigário da Vara de Vila Boa", Sociedade e Cultura, vol. 9, n. 1, Goiânia, 2006, p. 91-92.
} 
uma conquista tão remota, onde a distancia faz a regularidade do Governo mais precisa. ${ }^{33}$

Contudo, a partir de 1775, uma ordem do rei de Portugal fixou a contribuição anual dos cofres da Capitania de Goiás em 8 (oito) arrobas de ouro. ${ }^{34}$ Reveladores a respeito das transferências e investimentos realizados pela Capitania de Goiás são os argumentos utilizados pelo governador de Mato Grosso, Luiz de Albuquerque de Mello Pereira e Cáceres, em carta de outubro de 1776, escrita de Vila Bela, endereçada aos governadores de Goiás, na tentativa de sensibilizá-los para os problemas enfrentados pelo governo das minas de Cuiabá.

Alegando não ter podido evitar grandes despesas, Pereira e Cáceres, levado, principalmente,

pelo bem fundado receio de que os nossos vizinhos quisessem intentar alguma irrupção repentina por esta dilatadíssima fronteira, assim como praticam pelas Províncias do Sul,

afirma ter movimentado as tropas militares com o objetivo de ocupar "os lugares de perigo" nos limites das províncias de Chiquitos e Moxos, promovendo um arranjo militar de custo bastante elevado. Além disso, devido à mesma desconfiança com relação aos espanhóis, foi obrigado a socorrer com munição, pessoal e alimento o destacamento de Nova Coimbra, distante 200 léguas ao sul de Cuiabá. ${ }^{35}$

Some-se, ainda, às ações citadas pelo governador, financiadas com o ouro transferido da Capitania de Goiás, a construção do forte do Príncipe da Beira, distante 170 léguas de Vila Bela, e as atividades desenvolvidas na nova povoação de Vila Maria, constituída essencialmente de índios provenientes das missões espanholas de Chiquitos, "que Sua Majestade manda atrair a todo custo", formando tropas militares para a defesa do território português. Assim, de acordo com o governador de Mato Grosso, a aplicação do ouro de Goiás promovia "os dois importantíssimos fins de aumentar este Estado, e destruir o vizinho por aquela parte, de que nos pode resultar grande dano em tempo de guerra" ${ }^{36}$

De acordo, ainda, com o governador Pereira e Cáceres, a todo esse dispêndio realizado devem-se acrescentar os gastos com a "extraordinária Folha Militar" e "a política, que se não pode diminuir", pois é preciso, por outro lado, satisfazer o pagamento de credores, para que não se penalize "o progresso do comércio",

\footnotetext{
${ }^{33} \mathrm{AHU} / \mathrm{GO} /$ Anexo ao ofício do governador e capitão-general de Goiás, Luís da Cunha Menezes, ao secretário de estado da Marinha e Ultramar, Martinho de Melo e Castro, sobre a remessa com que anualmente se socorre a capitania de Mato Grosso e remetendo mapa e relação de todas as remessas saídas de Goiás para a dita capitania; Vila Boa de Goiás, 9 de julho de 1779 [Cx. 31, D. 1979].

${ }^{34} / \mathrm{dem}$, Ibidem.

${ }^{35} \mathrm{AHU} / \mathrm{GO} / \mathrm{Anexo}$ ao ofício do governador e capitão-general de Goiás, Luís da Cunha Menezes, ao secretário de estado da Marinha e Ultramar, Martinho de Melo e Castro, sobre a remessa com que anualmente se socorre a capitania de Mato Grosso e remetendo mapa e relação de todas as remessas saídas de Goiás para a dita capitania; Vila Boa de Goiás, 9 de julho de 1779 [Cx. 31, D. 1979]..

${ }^{36} / \mathrm{dem}$, Ibidem.
} 
não faltem "os gêneros da primeira necessidade" nos "Reais Armazéns", nem para o trabalho na "agricultura, e mineração", a fim de se evitar todo tipo de "prejuízo publico". ${ }^{37}$

De fato, o ouro produzido nas minas de Goiás teve grande importância para os movimentos portugueses na fronteira com os domínios espanhóis, à altura da Capitania de Mato Grosso, desde, pelo menos, o ano de 1757. Desta forma, Goiás cumpria o papel que lhe foi destinado como protagonista do projeto colonial nas regiões mineradoras, como base de sustentação da fronteira e estrutura de apoio logístico para os domínios lusitanos na América.

Contudo, os altos investimentos exigidos tornaram-se pesados para a economia de Goiás. Em 1776, o então governador José de Almeida Vasconcelos de Soveral e Carvalho denunciava à Junta de Administração da Real Fazenda as dificuldades para que a Capitania de Goiás continuasse com os repasses dos valores determinados pelo monarca. Afirmando ter socorrido a Capitania de Mato Grosso, desde 1772, ano de sua posse no governo de Goiás, com a quantia de oito arrobas de ouro, para o ano de 1777, o governador daquela Capitania havia solicitado um valor ainda mais alto: dez arrobas. Insatisfeito, Soveral e Carvalho argumenta que esse valor corresponde a quase todo o rendimento dos Quintos recolhidos naquele ano. Aparentemente irritado com o alto valor do repasse solicitado, aproveita a oportunidade para fazer um verdadeiro desabafo:

E devendo ponderar a essa Junta que aquele rendimento tem aplicações certas e determinadas, que se não podem evadir exaurindo-se o seu produto para Mato Grosso, e que antes pelo contrario e na forma das ordens de Sua Majestade deve cada uma das Capitanias economizar os seus rendimentos de modo que por eles façam suprir as despesas que lhes competem independentes de socorrerem umas a outras [...]. Ficará de acordo em não exceder a remessa costumada para Mato Grosso insinuando àquela Capitania que procure os meios eficazes de se lhe moderar ainda essa mesma remessa para o que também na presente ocasião se escreve ao Governador e Capitão General da referida Capitania fazendo se lhe a mesma recomendação o que se participa a essa Junta. ${ }^{38}$

Na senda de Soveral e Carvalho, seu sucessor, Luiz da Cunha Menezes, apesar de determinar o envio da remessa anual ao governador de Mato Grosso, após descrever as dificuldades pelas quais passa a Capitania, condiciona o envio do ouro às possibilidades da economia de Goiás:

\footnotetext{
${ }^{37} \mathrm{AHU} / \mathrm{GO} / \mathrm{Anexo}$ ao ofício do governador e capitão-general de Goiás, Luís da Cunha Menezes, ao secretário de estado da Marinha e Ultramar, Martinho de Melo e Castro, sobre a remessa com que anualmente se socorre a capitania de Mato Grosso e remetendo mapa e relação de todas as remessas saídas de Goiás para a dita capitania; Vila Boa de Goiás, 9 de julho de 1779 [Cx. 31, D. 1979].

${ }^{38} \mathrm{AHU} / \mathrm{GO} / \mathrm{Anexo}$ ao ofício do governador e capitão-general de Goiás, Luís da Cunha Menezes, ao secretário de estado da Marinha e Ultramar. Martinho de Melo e Castro, sobre a remessa com que anualmente se socorre a capitania de Mato Grosso e remetendo mapa e relação de todas as remessas saídas de Goiás para a dita capitania; Vila Boa de Goiás, 9 de julho de 1779 [Cx. 31, D. 1979].
} 
Determino neste mesmo ano fazer remeter lhe as ditas oito arrobas de ouro, se o poder conseguir, ou a quantia que me for possível, pois em uma Capitania fronteira, não convém que se lhe conheçam fatias de forças nem ainda nos próprios pagamentos. ${ }^{39}$

Entretanto, em que pese a crescente insatisfação dos governadores de Goiás, as peculiaridades da região de fronteira, a insegurança e o receio dos espanhóis operavam a favor da Capitania de Mato Grosso.

Naqueles “últimos domínios de Sua Majestade”, os privilégios pareciam consideráveis e necessários: um estímulo fiscal concedido pela rainha D. Maria I aos mineradores de Mato Grosso, em vigor até o ano de 1779, conhecido como indulto do meio-quinto de ouro, estimulava o recolhimento do imposto real. Tal concessão, contudo, ao mesmo tempo em que reduzia as receitas das minas de Cuiabá, pressionava, por conseguinte, os cofres já desfalcados da Capitania de Goiás. Enquanto perdurou, essa concessão esteve sempre presente nas alegações dos governadores de Mato Grosso, como meio de justificar as transferências provenientes de Goiás.

Desta forma, em 1778, o governador Pereira e Cáceres fazia projeções otimistas para a economia das minas de Mato Grosso, com a expectativa gerada pelo fim do indulto do quinto (privilégio temporário concedido pela Coroa, que consistia em uma redução no valor do imposto cobrado pelo ouro extraído na Capitania), a partir do ano de 1780. Ao alertar os governadores de Goiás sobre a extrema pobreza em que se encontrava sua Capitania, insistia ser indispensável o repasse de oito arrobas de ouro para o ano de 1779. Colocava, contudo, panos quentes na ferida provocada nas finanças da Capitania vizinha. Procurando amenizar os efeitos negativos de sua solicitação, se dizia lisonjeado

[...] de que já para o sucessivo [ano] de 1780 se não precisará de tão quantiosa soma, pelo maior alivio de dividas, e acréscimo de Rendimento que esperamos na Casa da Fundição desta Capital [Vila Bela], por que terá findado o Privilégio ou Indulto do meio Quinto do ouro, que a mesma Senhora [D. Maria I] foy servida conceder a estes Povos. ${ }^{40}$

Finalmente, depois de 22 anos transferindo, em média, oito arrobas de ouro anuais aos governadores de Mato Grosso, ${ }^{41}$ diante das incansáveis reclamações dos governadores da Capitania de Goiás e com o fim do Indulto do

\footnotetext{
${ }^{39} \mathrm{AHU} / \mathrm{GO} / \mathrm{AnexO}$ ao ofício do governador e capitão-general de Goiás, Luís da Cunha Menezes, ao secretário de estado da Marinha e Ultramar, Martinho de Melo e Castro, sobre a remessa com que anualmente se socorre a capitania de Mato Grosso e remetendo mapa e relação de todas as remessas saídas de Goiás para a dita capitania; Vila Boa de Goiás, 9 de julho de 1779 [CX. 31, D. 1979].

${ }^{40} \mathrm{AHU} / \mathrm{GO} / \mathrm{Anexo}$ ao ofício do governador e capitão-general de Goiás, Luís da Cunha Menezes, ao secretário de estado da Marinha e Ultramar, Martinho de Melo e Castro, sobre a remessa com que anualmente se socorre a capitania de Mato Grosso e remetendo mapa e relação de todas as remessas saídas de Goiás para a dita capitania; Vila Boa de Goiás, 9 de julho de 1779 [Cx. 31, D. 1979].

${ }^{41} / \mathrm{dem}$, ibidem. Parece evidente que os repasses e as ajudas financeiras para a Capitania de Mato Grosso foram efetuadas desde a fundação das duas Capitanias, em 1749. Contudo, oficialmente, a contribuição passa a ser efetuada regularmente como decorrência da provisão real de 7 de julho de 1757.
} 
Meio Quinto, em 8 de julho de 1779, a rainha, D. Maria I, determina a alteração dos valores dos repasses realizados, reduzindo-os e limitando-os a 300 marcos de ouro por ano.

Apesar disso, não teve fim o compromisso estabelecido desde a criação das duas Capitanias, no qual os governadores de Goiás arcavam com a manutenção das atividades desenvolvidas na fronteira dos dois impérios, no coração da América do Sul. No entanto, muito embora as transferências de ouro não tenham sofrido solução de continuidade, o ano de 1780 representou, certamente, um ponto de inflexão e um alívio para as finanças da Capitania de Goiás.

\section{Cartografia, tratados e território: Goiás na fronteira entre dois impérios}

Como vemos, a criação das prelazias e das Capitanias de Goiás e Mato Grosso devem ser percebidas como ações conjuntas que compõem um projeto mais amplo estabelecido por Lisboa. Desde logo, o momento essencial na trajetória ascendente das ações do monarca na região coincide com a demarcação dos limites territoriais entre as possessões de Portugal e Espanha, o que só aconteceu com os acordos estabelecidos por meio do Tratado de Madri, firmado em 13 de janeiro de $1750 .{ }^{42}$ Contudo, as linhas gerais que definem e dão forma à sua plena execução podem ser identificadas antes de 1749 .

A fundação de Vila Real do Senhor Bom Jesus do Cuiabá e, mais tarde, a criação de Vila Boa de Goiás indicam que havia uma consciência específica por parte da Coroa com relação aos avanços sobre a fronteira oeste da América, descumprindo e violando as cláusulas estabelecidas pelo Tratado de Tordesilhas. ${ }^{43}$ Contudo, se Portugal violava os limites do lado ocidental

\footnotetext{
$\overline{42} \mathrm{O}$ Tratado de Madri foi firmado entre D. João V de Portugal e Fernando VI de Espanha, a 13 de janeiro de 1750, com o objetivo de definir os limites entre as respectivas colônias sul-americanas, pondo fim, assim, às constantes disputas. O objetivo do Tratado de Madri era substituir o de Tordesilhas, o qual já não era mais respeitado na prática. As negociações basearam-se no chamado Mapa das Cortes, privilegiando a utilização de rios e montanhas para demarcação dos limites geográficos. O diploma consagrou o princípio do direito privado romano do uti possidetis, ita possideatis (quem possui de fato deve possuir de direito), delineando os contornos aproximados do Brasil de hoje. Sobre este assunto e seus desdobramentos, ver, especialmente, Jaime Cortesão, Alexandre de Gusmão e o Tratado de Madrid, Lisboa, Livros Horizonte, 1984.

${ }^{43}$ Sobre a cartografia setecentista de Goiás e Mato Grosso, ver Leonora de Castro Barbo; Andrey Rosenthal Schlee, "As estradas coloniais na Cartografia Setecentista da Capitania de Goiás", Anais do / Simpósio Brasileiro de Cartografia Histórica, Paraty, 2011, p. 1-20; Antônio César Caldas Pinheiro; Gustavo Neiva Coelho (orgs.), O diário de viagem do Barão de Mossâmedes: 1771-1773, Goiânia, Trilhas Urbanas, 2006; Antônio Teixeira Neto, "Cartografia, território e poder: dimensão técnica e política na utilização de mapas", Boletim Goiano de Geografia, vol. 26, n. 2, 2006, p. 49-69; André Ferrand Almeida, "Entre a Guerra e a Diplomacia: os conflitos luso-espanhóis e a cartografia da América do Sul (1702-1807)”, In: João Carlos Garcia (coord.), A Nova Lusitânia: imagens cartográficas do Brasil nas coleções da Biblioteca Nacional (1700-1822), Lisboa, Comissão Nacional para as Comemorações dos Descobrimentos Portugueses, 2001; Mario Clemente Ferreira, "Cartografar o sertão: a representação de Mato Grosso no século XVIII", In: I/ Simpósio Luso-Brasileiro de Cartografia Histórica, Lisboa, 2007, p. 6-7; Tiago Kramer de Oliveira, "Entre dois impérios: as conquistas portuguesas e ruralidade no centro da América do Sul (1734-1750)", In: Leny C. Anzai; Maria Cristina Bohn Martins (orgs.), Histórias coloniais em áreas de fronteiras: índios, jesuítas e colonos, São Leopoldo, Oikos/Unisinos; Cuiabá, Ed. UFMT, 2008, p. 17-49
} 
do globo terrestre, a Espanha, por sua vez, fazia o mesmo do lado oriental. ${ }^{44}$ Deste modo, a posição geoestratégica de Vila Boa de Goiás, fincada além dos marcos definidos pelo Tratado de Tordesilhas, é suficiente para percebermos o quanto Vila Real do Senhor Bom Jesus do Cuiabá encontrava-se avançada e resolutamente no interior do território pertencente à Coroa espanhola (Mapa 2).

Sabemos que, apesar de sua antiguidade e das frequentes violações, ao menos teoricamente as disposições do Tratado de Tordesilhas permaneceram em vigor entre os dois reinos até 1750, ano de conclusão dos acordos que selam o Tratado de Madri. Durante todo esse longo período, uma série de fatores dificultou a localização exata da linha divisória entre as possessões dos reinos ibéricos sobre o globo terrestre: a incerteza a respeito do marco inicial das 370 léguas, as dúvidas existentes à época quanto à dimensão real da légua, da longitude e, até mesmo, com relação às reais dimensões do planeta. Se os cartógrafos do século XVI delineiam a linha imaginária do tratado entre $42^{\circ} 30^{\prime}$ e $49^{\circ} 46^{\prime}$ a Oeste de Greenwich e admitindo-se, como o faz Frank da Costa, a hipótese segundo a qual a légua adotada em Tordesilhas fosse a de Fernandez de Enciso e de Francisco Falero ${ }^{45}$ (isto é, 162/3 léguas por grau, e não 15,como pensavam Colombo e Américo Vespúcio, nem 17 1/2, como queriam Pedro Nunes e Pedro Mártir, ou nem mesmo 18, de acordo com Duarte Pacheco Pereira), a linha passaria por $48^{\circ} 35^{\prime} 25^{\prime \prime}$ Oeste, no Ocidente, e $13^{\circ} 24^{\prime} 35^{\prime \prime}$ Leste, no Oriente. Isto é, o marco do lado ocidental, que é o que nos interessa aqui, estaria muito próximo de Vila Boa de Goiás, cuja latitude e longitude eram conhecidas com grande proximidade pelos geógrafos portugueses de $1750 .{ }^{46}$

\footnotetext{
${ }^{44}$ Estudando as manifestações de interesse pelas regiões polares e, mais especificamente, o problema político que envolve a apropriação da Antártida, João Frank da Costa lembra que "em conseqüência da descoberta das índias Ocidentais por Cristóvão Colombo, os Reis Católicos, que quebravam destarte o monopólio das novas terras reconhecido a Portugal por numerosas bulas pontificais, esforçaram-se em obter de Alexandre VI uma proteção jurídica (bulas Inter Caetera e Eximiae Devotionis). Finalmente, a segunda bula Inter Caetera, de 4 de maio de 1493 (segundo parece, apenas expedida em junho) concedia aos Reis Católicos, seus herdeiros e sucessores as ilhas e terras firmes, descobertas ou por descobrir, ao ocidente de uma linha traçada, do Pólo Norte ao Pólo Sul, a cem léguas das ilhas dos Açores ou de Cabo Verde. Sabe-se igualmente que a linha de demarcação entre os domínios de Espanha e de Portugal foi transferida para 370 léguas ao ocidente das ilhas de Cabo Verde, pelo Tratado de Tordesilhas, de 7 de junho de 1494. As cláusulas desse instrumento foram confirmadas pela bula Ea quae probono pacis, de 24 de janeiro de 1506, do Papa Júlio II. Apesar das violações cometidas pela Espanha no Oriente e Portugal no Ocidente, tais disposições permaneceram teoricamente em vigor entre as duas potências, até o Tratado de Madri, de 1750". João Frank da Costa, "Antártida: o problema político", Revista Brasileira de Política Internacional, n. 119-120, Rio de Janeiro, 1987, p. 52-53.

${ }^{45}$ Martin Fernandez de Enciso, habitante de Sevilha, imprimiu, em 1519, o sumário de geografia a pedido do imperador Carlos V. Ele acrescenta a esse tratado, destinado aos navegadores e marinheiros, tudo que se conhecia à época sobre a teoria e a prática de sua profissão. Francisco Falero era português e irmão de Rui Falero. Ambos chegaram à Espanha com Magellan. Sobre eles, ver Douflot de Mofras, Recherche sur le progrès de l'astronomie et des sciences nautiques en Espagne. Extraites des ouvrages espagnols de Don Martin Fernandez de Navarrete, Paris, Imprimerie Royale, 1839.

${ }^{46}$ Referindo-se aos erros cartográficos presentes nos mapas utilizados para as negociações que conduziram ao Tratado de Madri, Mario Clemente Ferreira lembra que Alexandre de Gusmão conhecia com muita aproximação o traçado do meridiano de Tordesilhas, bem como a latitude e longitude de Vila Boa de Goiás, calculadas apenas com um erro aproximado de $1^{\circ}$ (um grau) pela missão dos padres matemáticos. Mário Clemente Ferreira, "O Mapa das Cortes e o Tratado de Madrid", Varia Historia, vol. 23, n. 37, Belo Horizonte, 2007, p. 65.
} 


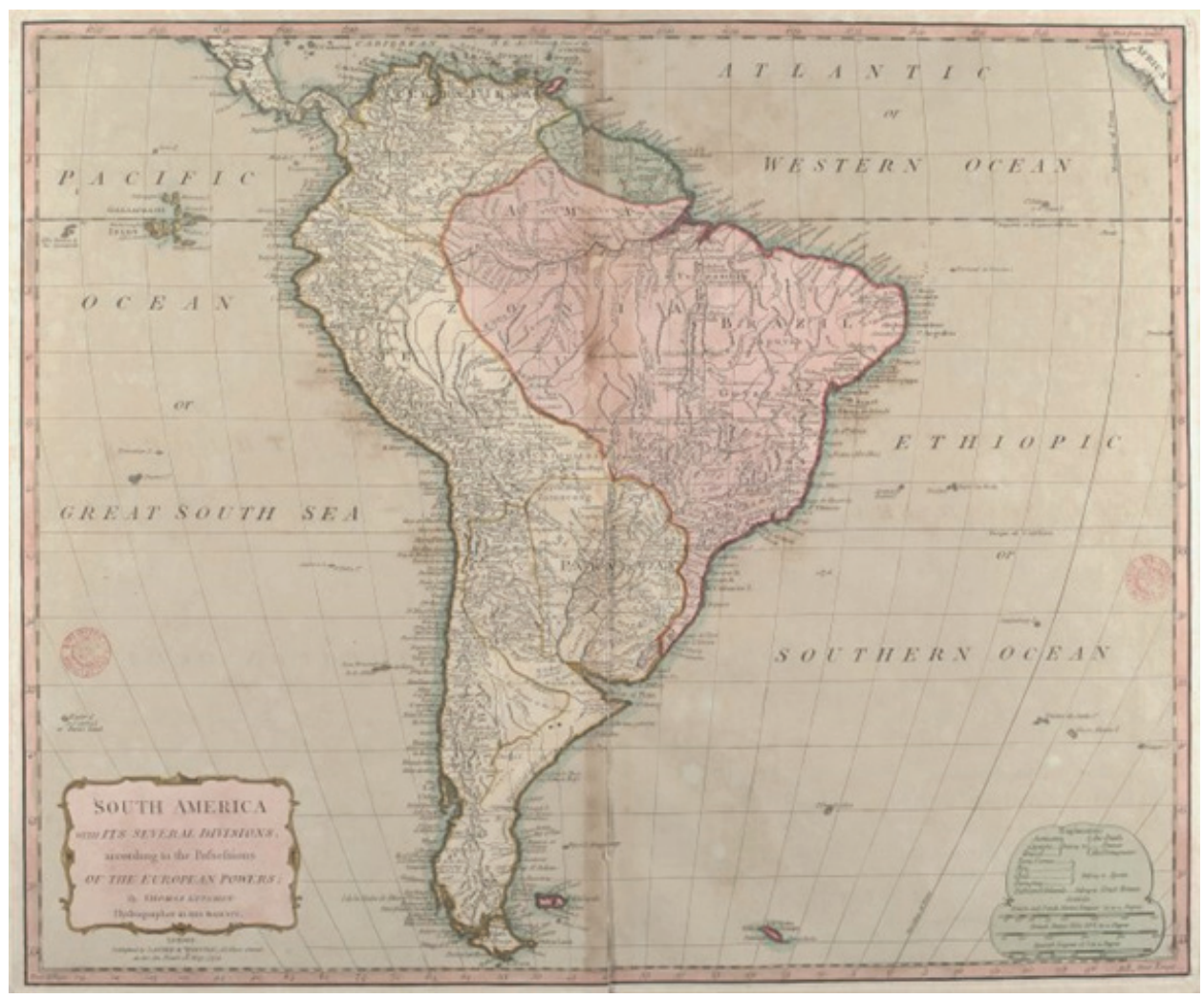

Mapa 2. Limites da fronteira oeste da América portuguesa sobre os domínios espanhóis. ${ }^{\text {}}$

Sabemos hoje que a posição exata de Vila Boa de Goiás está definida pelas coordenadas geográficas $15^{\circ} 56^{\prime} 04^{\prime \prime}$ de latitude Sul e $50^{\circ} 08^{\prime} 25^{\prime \prime}$ de longitude Oeste. Neste caso, se considerarmos as coordenadas do meridiano definidas pelo Tratado de Tordesilhas, como admitidas acima, temos que Vila Boa encontrava-se avançada em pleno território espanhol em, exatamente, $1^{\circ} 33^{\prime} 00^{\prime \prime}$ (um grau e trinta e três minutos), ou seja, cerca de 41 léguas ou, ainda, 246 quilômetros. Se os geógrafos portugueses da década de 1740 conheciam com erro aproximado de apenas $1^{\circ}$ (um grau) a longitude de Vila Boa, podemos concluir que o rei de Portugal sabia muito bem onde pisava e, por isso, investia pesado na fronteira visando garantir a posse de um amplo território e suas riquezas naturais que, teoricamente, pertenciam à Espanha.

Neste contexto, o alargamento definitivo das conquistas portuguesas na América apenas seria consolidado com as negociações efetuadas em função do Tratado de Madrid, momento em que o conhecimento do território e

\footnotetext{
'Thomas Kitchin (1718-1784). South America with its several divisions, according to the possessions of the european powers [Material cartográfico]/by Thomas Kitchin, Hydrographer to His Magesty. Contém impressa a seguinte referência à datação: "as the Act Directs 12th May, 1794". CDU 918(084.3). 912"17"(084.3). Cartografia do Brasil nas coleções da Biblioteca Nacional (1700-1822), Biblioteca Nacional, Lisboa.
} 
sua representação por meio dos mapas e cartas geográficas foram de crucial importância, pois, como lembra Clemente Ferreira, "sintetizavam o que era conhecido e compreendido, suposto ou até ignorado acerca de um determinado espaço ou território".47

Nesse item, a superioridade dos portugueses, em contraposição à ausência de mapas elaborados em Espanha, durante o período que antecede o acordo de Madri, acabou por garantir uma negociação favorável às suas pretensões. Por um lado, um prolongado descuido espanhol no acompanhamento sistemático das longitudes conferia a Portugal uma enorme autonomia em sua movimentação na fronteira. Por outro, uma notória carência de informações geográficas, sobretudo na região de Chiquitos, limitava a capacidade dos negociadores espanhóis por desconhecerem até onde os portugueses avançavam em Mato Grosso. ${ }^{48}$

Nesse contexto, a Coroa portuguesa elabora, na forma de texto, um “projeto do tratado de limites", enviado por Lisboa aos negociantes espanhóis, em novembro de 1747, anunciando, ao mesmo tempo, que preparava uma carta geográfica complementar, o Mapa das Cortes, ${ }^{49}$ a partir da qual seria estabelecido o acordo diplomático de $1750 .^{50}$ Para a confecção desse mapa, foi fundamental a sistematização das informações obtidas por meio das incursões realizadas por sertanistas tanto de Mato Grosso quanto de Goiás, utilizadas para a composição de uma carta geográfica anterior à elaboração do Mapa das Cortes e que lhe serviu de orientação: trata-se do mapa de 1746, elaborado sob os auspícios do governador do Rio de Janeiro, Gomes Freire de Andrade, provavelmente, a pedido de Alexandre de Gusmão.

Com foco nos territórios vizinhos ao domínio espanhol, a concepção do mapa de 1746 apresenta, sobretudo, o conjunto das regiões mineiras, notadamente o percurso das monções de São Paulo até Cuiabá e o caminho terrestre alternativo ligando o extremo oeste às minas de Goiás, representando, igualmente, os contatos estabelecidos pelos portugueses, durante as décadas de 1730 e 1740, com as missões espanholas de Moxos e Chiquitos, bem como as viagens exploratórias do sertanista Amaro Leite Moreira realizadas no interior de Goiás. ${ }^{51}$

Assim, ao mesmo tempo em que se trabalhava na definição da fronteira entre os dois impérios, construía-se, nos espaços internos da América portuguesa, um vasto conhecimento baseado nas informações locais, que proporcionavam, por sua vez, novas redefinições quanto aos limites das microfronteiras

\footnotetext{
${ }^{47}$ Mário Clemente Ferreira, "O Mapa das Cortes e o Tratado de Madrid", Varia Historia, vol. 23, n. 37, Belo Horizonte, 2007, p. 52.

${ }^{48} / \mathrm{dem}$, Ibidem.

${ }^{49}$ Carta de M. A. de Azevedo Coutinho para Tomás da Silva Teles; Lisboa, 14 de dezembro de 1748, apud Jaime Cortesão, Alexandre de Gusmão e o Tratado de Madrid, parte IV, tomo I, documento 60, p. 252.

${ }^{50}$ Jaime Cortesão, História do Brasil nos Velhos Mapas, vol. 2, Rio de Janeiro, Ministério das Relações Exteriores Instituto Rio Branco, 1971, p. 251. Sobre o Mapa das Cortes, ver Jorge Pimentel Cintra, "O mapa das cortes: perspectivas cartográficas", Anais do Museu Paulista, vol. 17, n. 2, São Paulo, jul.-dez. 2007, p. 39-61.

${ }^{51}$ Mário Clemente Ferreira, "O Mapa das Cortes e o Tratado de Madrid", Varia Historia, vol. 23, n. 37, Belo Horizonte, 2007, p. 60-61.
} 
regionais. Vale lembrar que a indefinição das linhas geográficas demarcatórias do território associado às minas de Goiás sempre despertou os interesses das autoridades coloniais, sendo objeto e alvo de sérias disputas envolvendo representantes da Coroa, autoridades e negociantes locais e, até mesmo, membros do clero com atuação na América portuguesa.

Por isso, assim que assumiu o governo da Capitania de Goiás, Marcos de Noronha foi orientado por Lisboa a proceder a uma análise, bem como à definição das questões ligadas aos limites da Capitania, levando em conta, principalmente, as fronteiras com a Capitania de Mato Grosso. Assim, em janeiro de 1750, em carta ao rei de Portugal, o governador apresentava um esboço bastante preciso quanto aos limites da Capitania. ${ }^{52}$

A superioridade dos portugueses, em
contraposição à ausência de mapas elaborados
em Espanha, acabou por garantir uma
negociação favorável às suas pretensões

Esse esforço de Marcos de Noronha resultou na confecção de um mapa em 1751, de autoria de Francisco Tosi Colombina, ${ }^{53}$ utilizado, em 1753, para apresentar ao monarca a demarcação dos limites da Capitania de Goiás e integrando, ao mesmo tempo, o "projeto de limites" elaborado em Lisboa. Nessa carta geográfica, o território de Goiás aparece pela primeira vez com suas características e formato bastante peculiares, constituindo-se, na opinião de Teixeira Neto, na "certidão de nascimento" de Goiás, numa analogia do que foi para o Brasil a carta de Pero Vaz de Caminha. ${ }^{54}$

Mas a primazia de Tosi Colombina foi posta em xeque. Antes mesmo de elaborar essa "certidão de nascimento" de Goiás, outro mapa,

\footnotetext{
${ }^{52} \mathrm{AHU} / \mathrm{GO} /$ Carta do governador e capitão-general de Goiás, Marcos de Noronha, ao rei D. João V, em resposta à provisão sobre como se deve proceder quanto aos limites geográficos da capitania de Goiás; Vila Boa de Goiás, 12 de janeiro de 1750 [Cx. 6. D. 429].

${ }^{53}$ De acordo com o secretário de governo Ângelo Santos Cardoso, Tosi Colombina chegou a Goiás em 1749, integrando a comitiva do novo ouvidor Agostinho Luiz Vieira, na qualidade de cosmógrafo (como eram conhecidos os antigos cartógrafos), no mesmo período da chegada do primeiro governador Marcos de Noronha. Cf. AHU/GO/Ofício do secretário do governo de Goiás, Ângelo dos Santos Cardoso, ao secretário de estado da Marinha e Ultramar, Diogo de Mendonça Corte Real, sobre a descoberta das minas de Goiás; sua povoação; o caráter dos primeiros mineiros e profissionais liberais; os governos civil e eclesiástico e os problemas nela existentes; Vila Boa de Goiás, 15 de abril de 1755 [Cx. 12, D. 740]. Segundo Teixeira Neto, "sua obra cartográfica, da qual se gabava como sendo uma das mais corretas que se fazia no Brasil, era na verdade uma cartografia expedita, prática, porque baseada apenas em informações de roteiros de bandeirantes e exploradores do sertão". Nem por isso, contudo, perde a sua importância no contexto dos mapas da época. Cf. Antônio Teixeira Neto, "Os caminhos de ontem e de hoje em direção a Goiás-Tocantins", Boletim Goiano de Geografia, vol. 21, n. 1, Goiânia, 2001, p. 58.

54"Mapa da Capitania de Goyaz e regiões circunvizinhas que mostra as comunicações entre as bacias do Prata e do Amazonas", de Francisco Tosi Colombina, Vila Boa de Goiás, 6 de abril de 1751. O mapa constitui-se em exemplar manuscrito aquarelado, conservado na Diretoria do Serviço Geográfico, no Rio de Janeiro. Existe um outro exemplar no Arquivo Público de Minas Gerais, bem como cópias atuais conservadas na Biblioteca Nacional do Rio de Janeiro.
} 
preparado anteriormente por um geógrafo desconhecido, parece não apenas ter ofuscado a precedência de Colombina, sugerida por Teixeira Neto, como também teria servido de referência e ponto de partida para o seu trabalho. ${ }^{55}$

De fato, sob a orientação do secretário de governo das minas de Goiás, Ângelo dos Santos Cardoso, outra carta geográfica foi confeccionada e enviada para Alexandre de Gusmão, ainda em maio de 1750. Em relatório dirigido a Sebastião José de Carvalho e Mello, Secretário de Estado a partir de 1750 e futuro marquês de Pombal, Santos Cardoso faz clara referência a um mapa anterior ao de Tosi Colombina que ele afirma textualmente ter enviado, pessoalmente, a Lisboa:

\begin{abstract}
Na mesma conjuntura que eu cheguei a esta Vila Em companhia do Senhor General Gomes Freire de Andrada", diz o secretário, "também veio um Italiano, por nome Francisco Tosi Columbina, na comitiva do ouvidor novo Agostinho Luiz Vieira, que Vinha então para esta Comarca; o qual Columbina daí a quase um ano, foi em companhia do mesmo Ouvidor correr a Comarca; e levou ordem do Senhor Conde dos Arcos General desta Capitania, para ir observando as alturas dos Arraiais, e situações da mesma Comarca; pela curiosidade que se lhe descobriu, de ser enfarinhado em Geografia; pediu-me o referido Columbina, a copia do Mapa, que eu já antecedentemente tinha na mão, de que havia remetido o original para a Corte a Alexandre de Gusmão, e dele se valeu para formar outro com pouca diferença, exceto em alguma exação das alturas dos graus, em que ficavam os Arraiais, e algum rio, ou sitio que descobriu de novo $[\ldots]^{56}$
\end{abstract}

Baseado nessas indicações e nas sugestões de Paulo Bertran, um interessante estudo a respeito do assunto confronta a preeminência dos mapas elaborados por Francisco Tosi Colombina. ${ }^{57}$

\title{
Conclusão
}

Finalmente, fundamentado nesse conjunto de informações, em setembro de 1751, o rei José I assina a provisão "Sobre a Medição da Colônia e

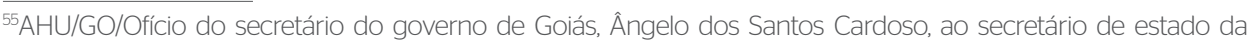
Marinha e Ultramar, Diogo de Mendonça Corte Real, sobre a descoberta das minas de Goiás; sua povoação; o caráter dos primeiros mineiros e profissionais liberais; os governos civil e eclesiástico e os problemas nela existentes; Vila Boa de Goiás, 15 de abril de 1755 [Cx. 12, D. 740].

${ }^{56} \mathrm{AHU} / \mathrm{GO} /$ Ofício do secretário do governo de Goiás, Ângelo dos Santos Cardoso, ao secretário de estado da Marinha e Ultramar, Diogo de Mendonça Corte Real, sobre a descoberta das minas de Goiás; sua povoação; o caráter dos primeiros mineiros e profissionais liberais; os governos civil e eclesiástico e os problemas nela existentes; Vila Boa de Goiás, 15 de abril de 1755 [Cx. 12, D. 740].

${ }^{57}$ Cf. Wilson Carlos Jardim Vieira Júnior; Andrey Rosenthal Schlee; Lenora de Castro Barbo, "Tosi Colombina, autor do primeiro mapa da Capitania de Goiás?", História e-história, Unicamp, 2010. Disponível em: <http:/l www.historiaehistoria.com.br>. Acesso em: 25 de maio de 2010. Conferir, também, em Paulo Bertran, História da terra e do homem no Planalto Central: eco-história do Distrito Federal, do indígena ao colonizador, Brasília, Verano, 2000 .
} 
Limites da América", dirigida ao governador do Rio de Janeiro, Gomes Freire de Andrade. Ao mesmo tempo, manda informar ao provedor da Fazenda Real da Capitania de Goiás que havia ajustado com El Rei de Castela um tratado de limites na América,

[...] para cessarem as disputas que entre os meus vassalos, e os daquela Coroa se movia ou se poderiam mover nas inteligências das linhas meridianas e imaginarias [...] reduzindo os limites das duas monarquias e as assinaladas no referido tratado com os nomes dos Rios, montes e países. ${ }^{58}$

Uma vez mais, a Fazenda Real, em Goiás, era acionada diretamente pelo rei de Portugal, sobre assunto de relevância indiscutível para a monarquia portuguesa: tratava-se de financiar, com o ouro produzido nas minas de Goiás, as despesas com os geógrafos e oficiais responsáveis pela demarcação e divisão das "terras da colônia".

Entretanto, de Vila Boa, a resposta do intendente e provedor, Anastácio da Nóbrega, foi fria e seca:

Porem sempre devo representar a Vossa Majestade, escreve o intendente ao rei de Portugal, que esta provedoria se acha onerada com tantos gastos, que a sua despesa excede a muito mais da sua receita, em gastos essencialmente necessários e com dificuldade grande se suprira a quaisquer que de novo sobrevenham..$^{59}$

Como vemos, se Anastácio da Nóbrega, em 1753, já emitia sinais de insatisfação com as exorbitantes somas em ouro despendidas em função da manutenção e proteção da fronteira no extremo oeste do Brasil, durante muito tempo ainda seria o ouro de Goiás a coluna vertical que daria sustentação financeira ao projeto colonial e às ambições do rei de Portugal na região central da América do Sul.

Em que pese os esforços realizados, os acordos definidos pelo Tratado de Madri tiveram vida curta, tendo feito, em muito pouco tempo, poderosos inimigos: os jesuítas espanhóis que haviam sido expulsos das Missões e os comerciantes impedidos de realizar o contrabando no rio da Prata. Seus protestos encontraram um inesperado apoio em Portugal, por parte do Marquês de Pombal. Na verdade, um novo acordo - o de El Pardo -, firmado em 12 de fevereiro de 1761, anulou o de Madri. Mas as bases geográficas e os fundamentos jurídicos pelos quais Alexandre de Gusmão tanto lutara em 1750 acabaram prevalecendo e, em 1777, aqueles princípios

\footnotetext{
${ }^{58} \mathrm{AHU} / \mathrm{GO} / \mathrm{Carta}$ do intendente e provedor da Fazenda Real de Goiás, Anastácio da Nóbrega, ao rei José I, sobre o cumprimento da provisão ordenando assistir os geógrafos e oficiais da divisão das terras da colônia, com o dinheiro que o governador e capitão-general do Rio de Janeiro, Gomes Freire de Andrade, determinasse e acerca da Provedoria de Goiás se encontrar bastante onerada; Vila Boa de Goiás, 30 de maio de 1753 [Cx. 8, D. 575].

59/dem, Ibidem.
} 
anulados ressurgiram no Tratado de Santo Ildefonso. ${ }^{60}$ A dimensão estratégica do resultado final não pode ser ignorada. Na opinião do geógrafo Teixeira Neto,

Tudo isto resultou em um dos projetos geopolíticos mais bem elaborados ao longo da história do Brasil: o da preparação diplomática, técnica e científica do Tratado de Madri - assinado em 1750 entre Portugal e Espanha -, que deu forma, solidez e legitimidade às fronteiras e limites do Brasil e à ocupação, povoamento e urbanização de todas as terras que hoje formam o Centro-Oeste e a Amazônia brasileiros. ${ }^{61}$

À luz deste raciocínio, percebemos a região das minas de Goiás enquanto eixo geopolítico central no projeto colonial dirigido por Lisboa para a América portuguesa. Se a implantação de um aparato administrativo, jurídico e religioso estabelece, paulatinamente, o poder de controle da Coroa na região, a preeminência dos interesses do monarca aparece de forma mais sólida por meio do estímulo à fundação de vilas e cidades. Assim, em meados do século XVIII, a presença estratégica do rei de Portugal na fronteira oeste da América portuguesa estava consolidada por meio do estabelecimento das bases materiais do domínio português frente ao domínio espanhol.

Nessa paisagem construída no coração da América, a Capitania de Goiás e sua capital, Vila Boa, se constituem num posto avançado a oeste, situado além dos limites da linha definida pelo Tratado de Tordesilhas, que atende aos interesses do governo português em duas dimensões essenciais: enquanto centro de uma estrutura fiscal e administrativa capaz de viabilizar a extração do ouro e, ao mesmo tempo, como ponto de apoio estratégico - oferecendo suporte material, humano e financeiro - , ancorando e garantindo, na condição de uma base organizada, o avanço paulatino desta última fronteira colonial.

\footnotetext{
${ }^{60}$ Tratado de Santo Ildefonso é o acordo assinado em 10 de outubro de 1777 na cidade de San Ildefonso, na província espanhola de Segóvia, com o objetivo de encerrar a disputa entre Portugal e Espanha pela posse da colônia sul-americana do Sacramento, situação que se prolongava desde a Paz de Utrecht e a guerra de 1735-1737. O tratado foi intermediado pela Inglaterra e a França, que tinham interesses políticos internacionais na pacificação dos dois países ibéricos. Com a assinatura do tratado, a rainha de Portugal, D. Maria I, e o rei da Espanha, Carlos III, praticamente revalidaram o Tratado de Madrid (1750) e concederam fundamento jurídico a uma situação de fato: os espanhóis mantiveram a colônia e a região dos Sete Povos das Missões, que depois passou a compor grande parte do estado do Rio Grande do Sul e do Uruguai; em troca, reconheceram a soberania dos portugueses sobre a margem esquerda do rio da Prata, cederam pequenas faixas fronteiriças para compensar as vantagens obtidas no sul e devolveram a ilha de Santa Catarina.

${ }^{61}$ Antônio Teixeira Neto, "Cartografia, território e poder: dimensão técnica e política na utilização de mapas", Boletim Goiano de Geografia, vol. 26, n. 2, Goiânia, 2006, p. 56.
} 